\title{
ANALISIS PENGARUH TINGKAT PROFITABILITAS, KEPUTUSAN INVESTASI, KEPUTUSAN PENDANAAN DAN KEBIJAKAN DIVIDEN TERHADAP NILAI PERUSAHAAN
}

\author{
Dian Indriyani \\ Tina Sulistiyani \\ Universitas Ahmad Dahlan
}

\begin{abstract}
ABSTRAK
This research was aimed to examine the influence of profitability level, investment decision, funding decision and dividend policy towards company value in companies affiliated in Jakarta Islamic Index (JII) listed in Indonesian Stock Exchange. Population and also research samples was companies that their stocks included in Jakarta Islamic Index (JII) calculation listed in Indonesian Stock Exchange of 2010-2012 periods that had a complete financial statement stated in Rupiah and paying dividend routinely during the research period numbered 6 companies. Dependent variables used i.e. company value (DPR) while its independent variable was profitability level (ROE), investment decision (PER), funding decision (DER) and dividend policy (DPR). This research used a panel data regression test device and classical assumption test. The independent variable influence testing towards dependent variable was performed partially through a statistical t-test. Based on the research result partially using $a$ statistical t-test showed that profitability level, investment decision and dividend policy significantly influenced company value.
\end{abstract}

Keywords: company value, profitability level,investment decision, funding decision, dividend policy

\section{PENDAHULUAN}

Sebuah perusahaan didirikan dengan tujuan untuk mencapai keuntungan maksimal atau laba yang sebesar-besarnya dan mengoptimalkan nilai perusahaan. Nilai perusahaan ditentukan oleh profitabilitas perusahaan. Profitabilitas merupakan suatu indikator kinerja yang dilakukan oleh manajemen perusahaan dalam mengelola kekayaan perusahaan yang ditunjukkan oleh laba yang dihasilkan perusahaan. Profitabilitas yang tinggi menunjukkan prospek perusahaan yang bagus sehingga investor akan merespon positif dan nilai perusahaan akan meningkat (Wahyudi dan Pawestri, 2006).
Sementara itu dalam memaksimumkan nilai perusahaan, menurut Murtini dalam Afzal dan Rohman (2012), manajemen perusahaan dapat melalukan tiga kebijakan, yaitu kebijakan pendanaan, investasi dan dividen. Kebijakan pendanaan adalah kebijakan manajemen keuangan untuk mendapatkan dana (baik dari pasar uang maupun pasar modal). Setelah mendapatkan dana, manajemen keuangan akan menginvestasikan dana yang diperoleh ke dalam perusahaan. Keputusan pendanaan didefinisikan sebagai keputusan yang menyangkut komposisi pendanaan yang dipilih oleh perusahaan (Hasnawati dalam Afzal dan Rohman, 2012). 
Keputusan yang menyangkut investasi akan menentukan sumber dan bentuk dana untuk pembiayaannya. Masalah yang harus dijawab dalam keputusan pendanaan yang dihubungkan dengan sumber dana adalah apakah sumber internal atau sumber eksternal, besarnya hutang atau modal atau modal sendiri, dan bagaimana tipe hutang dan modal yang akan digunakan, mengingat struktur pembiayaan akan menentukan cost of capital yang akan menjadi dasar penentuan required return (Hasnawati dalam Wijaya, dkk, 2010).

Tujuan memaksimumkan kemakmuran pemegang saham dapat ditempuh dengan memaksimumkan nilai sekarang atau present value semua keuntungan pemegang saham yang diharapkan akan diperoleh di masa yang akan datang. Kemakmuran pemegang saham akan meningkat apabila harga saham yang dimilikinya meningkat (Sartono, 2001). Salah satunya dapat dilihat dari seberapa besar perusahaan akan memberikan dividen kepada investor yang menanamkan modalnya di perusahaan tersebut.

Dividen merupakan sebagian laba yang dibagikan kepada pemegang saham. Bagi investor jumlah rupiah yang diterima dari pembayaran dividen risikonya lebih kecil daripada capital gain, selain itu dividen lebih dapat diperkirakan sebelumnya sedangkan capital gain lebih sulit untuk diperkirakan. Sehingga pembayaran dividen yang tinggi dapat diartikan bahwa perusahaan mempunyai prospek tingkat keuntungan yang baik. Sebaliknya, penurunan pembayaran dividen dapat diartikan bahwa prospek tingkat keuntungan perusahaan kurang baik yang tentunya akan berpengaruh terhadap nilai perusahaan (Halim, 2005).

Pembagian dividen tergantung dari keputusan setiap perusahaan itu sendiri, apakah perusahaan akanmembagikan dividenkepadapara pemegang saham atau akan ditahan dalam bentuk laba ditahan guna pembayaran investasi di masa yang akan datang. Karena besarnya pembagian dividen tersebut berdasarkan kemampuan suatu perusahaan dalam menghasilkan timbal balik dari suatu investasi itu sendiri.

Berdasarkanlatar belakangyang ada, maka rumusan masalah dalam penelitian ini adalah: (1) Apakah tingkat profitabilitas berpengaruh signifikan terhadap nilai perusahaan?; (2) Apakah keputusan investasi berpengaruh signifikan terhadap nilai perusahaan?; (3) Apakah keputusan pendanaan berpengaruh signifikan terhadap nilai perusahaan?; (4) Apakah kebijakan deviden berpengaruh signifikan terhadap nilai perusahaan.

\section{REVIEW LITERATUR DAN HIPOTESIS}

\section{Tingkat Profitabilitas}

Profitabilitas adalah hasil akhir dari sejumlah kebijakan dan keputusan manajemen perusahaan (Brigham dan Gapenski, 1996). Dengan demikian dapat dikatakan profitabilitas perusahaan merupakan kemampuan perusahaan dalam menghasilkan laba bersih dari aktivitas yang dilakukan pada periode akuntansi.

Profitabilitas yang tinggi menunjukkan prospek perusahaan yang baik sehingga investor akan merespon positif sinyal tersebut dan nilai perusahaan akan meningkat (Sujoko dan Soebintoro, 2007). Investor menanamkan saham pada sebuah perusahaan dengan tujuan untuk mendapatkan return, yang terdiri dari yield dan capital gain. Semakin tinggi kemampuan memperoleh laba, maka semakin besar return yang diharapkan investor, sehingga menjadikan nilai perusahaan menjadi lebih baik.

Rasio profitabilitas dalam penelitian ini diwakili oleh return on equity (ROE). ROE digunakan sebagai pengukuran rasio profitabilitas karena memiliki keunggulan yaitu mudah dihitung dan dipahami. ROE merupakan rasio yang menunjukkan tingkat pengembalian yang diperoleh pemilik atau pemegang saham atas 
investasi di perusahaan. ROE membandingkan besarnya laba bersih terhadap ekuitas saham biasa. Semakin tinggi ROE menunjukkan bahwa semakin tinggi tingkat pengembalian terhadap investasi yang dilakukan dan semakin rendah ROE suatu perusahaan maka tingkat pengembaliannya akan semakin rendah pula. Seorang calon investor perlu melihat ROE suatu perusahaan sebelum memutuskan melakukan investasi supaya dapat mengetahui seberapa banyak yang akan dihasilkan dari investasi yang dilakukannya (Sitepu, 2010).

\section{Keputusan Investasi}

Investasi adalah komitmen atas sejumlah dana atau sumber daya lainnya yang dilakukan pada saat ini, dengan tujuan memperoleh sejumlah keuntungan di masa mendatang. Seorang investor membeli sejumlah saham saat ini dengan harapan memperoleh keuntungan dari kenaikan harga saham ataupun sejumlah dividen di masa yang akan datang (Tandelilin, 2001).

Suatu investasi dikatakan menguntungkan (profitable) kalau investasi tersebut bisa membuat pemodal menjadi lebih kaya. Dengan kata lain, kemakmuran pemodal menjadi lebih besar setelah melakukan investasi. Pengertian ini konsisten dengan tujuan memaksimumkan nilai perusahaan (Husnan, 1996).

Keputusan investasi merupakan salah satu faktor yang mempengaruhi nilai perusahaan, dimana keputusan investasi menyangkut keputusan tentang pengalokasian dana, baik dilihat dari sumber dana (yang dari dalam dan luar perusahaan) maupun pengguna dana untuk tujuan jangka pendek dan jangka panjang (Efni dkk, 2012).

Investasi dalam penelitian ini diukur dengan Price Earning Ratio (PER). Menurut Brigham dan Houston dalam Wijaya dkk. (2010), PER menunjukkan perbandingan antara closing price dengan laba per lembar saham (earning per share).

\section{Keputusan Pendanaan}

Keputusan pendanaan perusahaan menyangkut keputusan tentang bentuk dan komposisi pendanaan yang akan dipergunakan oleh perusahaan. Secara umum, dana dapat diperoleh dari luar perusahaan (external financing) maupun dari dalam perusahaan (internal financing). Keputusan tentang external financing sering disebut sebagai keputusan pendanaan, sedangkan internal financing menyangkut kebijakan dividen (Husnan, 1996).

Keputusan pendanaan ini berkaitan dengan keputusan perusahaan dalam mencari dana untuk membiayai investasi dan menentukan komposisi sumber pendanaan. Pendanaan perusahaan dapat dikelompokan berdasarkan sumber dananya yaitu pendanaan internal dan pendanaan eksternal.

Pendanaan berkaitan dengan pemilihan sumber dana, baik berasal dari internal maupun eksternal perusahaan itu sendiri. Pendanaan diukur dengan Debt to Equity Ratio (DER). Semakin tinggi nilai DER mengidentifikasikan semakin tinggi hutang perusahaan. Perusahaan yang memiliki hutang akan membayar bunga pinjaman yang akan mengurangi penghasilan kena pajak. Pengurangan pajak ini akan menambah laba perusahaan dan dana tersebut dapat dipakai untuk investasi perusahaan di masa yang akan datang ataupun untuk membagikan dividen kepada para pemegang saham. Apabila pembagian dividen tersebut dilakukan oleh perusahaan maka penilaian investor terhadap perusahaan akan meningkat ditujukan dengan naiknya harga saham yang merupakan indikator nilai perusahaan (Beirlian, 2012).

\section{Kebijakan Dividen}

Menurut Sumantoro dalam Wibowo (2008), dividen adalah keuntungan yang diperoleh perusahaan yang dibagikan kepada para pemilik perusahaan. Pembayaran dividen merupakan komunikasi secara tidak langsung kepada 
pemegang saham tentang tingkat profitabilitas yang dicapai perusahaan.

Kebijakan dividen disini dapat diukur dengan Dividen Payout Ratio (DPR). Nilai DPR yang tinggi pasti akan berimbas pada pembagian laba yang besar oleh perusahaan kepada pemegang saham.

Dividen merupakan sebagian laba yang dibagikan kepada pemegang saham, sehingga pembayaran dividen yang tinggi dapat diartikan bahwa perusahaan mempunyai prospek tingkat keuntungan yang baik. Sebaliknya, penurunan dividen dapat diartikan bahwa prospek tingkat keuntungan perusahaan kurang baik yang tentunya akan berpengaruh terhadap nilai perusahaan (Halim, 2005).

Fama dan French (1998) menemukan bahwa investasi yang dihasilkan dari kebijakan dividen memiliki informasi yang positif tentang perusahaan di masa yang akan datang, selanjutnya berdampak positif terhadap nilai. Hasnawati (2005) menemukan bahwa kebijakan dividen berpengaruh positif terhadap nilai perusahaan. Wahyudi dan Pawestri (2006) menemukan bahwa kebijakan dividen tidak berpengaruh terhadap nilai perusahaan.

\section{Nilai Perusahaan}

Tujuan utama perusahaan adalah untuk meningkatkan nilai perusahaan. Nilai perusahaan didefinisikan sebagai nilai pasar sebagai konsep penting bagi investor, karena merupakan indikator bagi pasar untuk menilai perusahaan secara keseluruhan. Nilai perusahaan dapat memberikan kemakmuran pemegang saham secara maksimum apabila harga saham perusahaan meningkat.

Menurut Jogiyanto dalam Rachmawati (2011), bahwa keberadaan PBV sangat penting bagi investor untuk menentukan strategi investasi di pasar modal karena melalui price to book value, investor dapat memprediksi saham-saham yang overvalued atau undervalued. Price to book value menggambarkan seberapa besar pasar menghargai nilai buku saham suatu perusahaan. Perusahaan yang berjalan dengan baik, umumnya memiliki rasio price to book value di atas satu, yang mencerminkan bahwa nilai pasar saham lebih besar dari nilai bukunya. Price to book value yang tinggi mencerminkan tingkat kemakmuran para pemegang saham, dimana kemakmuran bagi pemegang saham merupakan tujuan utama dari perusahaan.

Suatu perusahaan dikatakan mempunyai nilai yang baik jika kinerja perusahaan juga baik. Nilai perusahaan dapat tercermin dari harga sahamnya. Jika nilai sahamnya tinggi bisa dikatakan nilai perusahaannya juga baik. Karena tujuan utama perusahaan adalah meningkatkan kemakmuran pemegang saham (Gapensi dalam Wahidahwati, 2002 dan dikutip dalam Rachmawati, 2011).

Nilai perusahaan dapat tercermin dari rasio price to book value (PBV) yang diperoleh dengan membandingkan harga saham dipasar dan nilai bukunya. Semakin tinggi rasio PBV dapat diartikan semakin berhasil perusahaan menciptakan nilai bagi pemegang saham.

\section{Hipotesis}

$\mathrm{H}_{1}$ : Tingkat profitabilitas berpengaruh terhadap nilai perusahaan

$\mathrm{H}_{2}$ : Keputusan investasi berpengaruh terhadap nilai perusahaan

$\mathrm{H}_{3}$ : Keputusan pendanaan berpengaruh terhadap terhadap nilai perusahaan

$\mathrm{H}_{4}$ : Kebijakan deviden berpengaruh terhadap nilai perusahaan

\section{METODE PENELITIAN}

\section{Populasi, Sampel dan Teknik Pengambilan Sampel}

Populasi dalam penelitian ini adalah perusahaan yang tergabung dalam Jakarta Islamic Index (JII) dan terdaftar di Bursa Efek Indonesia (BEI) yaitu berjumlah 30 perusahaan. Sampel penelitian ini diperoleh dengan teknik purposive 
sampling, yaitu pengambilan sampel berdasarkan kriteria tertentu. Adapun kriteria pengambilan sampel yaitu: (1) Perusahaan yang masuk dalam indeks JI tahun 2010-2012; (2) Perusahaan yang rutin membagikan cash dividend berturut-turut selama periode penelitian yaitu tahun 2010-2012; (3) Perusahaan yang memiliki data-data lengkap yang dibutuhkan dalam penelitian selama periode 2010-2012.

Dari kriteria diatas diperoleh 6 perusahaan yang memenuhi kriteria untuk dijadikan sampel.

\section{Jenis dan Sumber Data}

Jenis data yang digunakan dalam penelitian ini adalah data kuantitatif berupa laporan keuangan yang dipublikasikan periode 2010-2012. Berdasarkan sumbernya, data yang digunakan dalam penelitian ini adalah data sekunder, yaitu data yang tidak diperoleh secara langsung. Data diperoleh dari pojok bursa pada Bursa Efek Indonesia.

\section{Teknik Pengumpulan Data}

Teknik pengumpulan data yang digunakan dalam penelitian ini adalah teknik dokumentasi yaitu pengumpulan data berupa rasio-rasio laporan keuangan perusahaan go public yang telah dipublikasikan di Bursa Efek Indonesia periode 2010-2012.

\section{Definisi Operasional Variabel \\ Variabel Dependen}

Nilai Perusahaan

Nilai perusahaan dalam penelitian ini didefinisikan sebagai nilai pasar karena perusahaan dapat memberikan kemakmuran pemegang saham secara maksimum apabila harga saham perusahaan meningkat (Hasnawati dalam Beirlian 2012). Nilai perusahaan diproksikan melalui Price to Book Value (PBV). Price to Book Value dapat dirumuskan sebagai berikut:

$$
\mathrm{PBV}=\frac{\text { Harga Pasar Per Lembar Saham }}{\text { Nitai Buku Per Lembar Saham }}
$$

PBV merupakan ukuran nilai yang diberikan pasar keuangan kepada manajemen dan organisasi perusahaan sebagai sebuah perusahaan yang terus tumbuh (Brigham dan Houston dalam Wijaya dkk, 2010). Nilainya diperoleh melalui perbandingan antara harga pasar per lembar saham dengan nilai buku per lembar saham.

\section{Variabel Independen}

Tingkat Profitabilitas

Tingkat profitabilitas dalam penelitian ini didefinisikan sebagai laba yang dihasilkan perusahaan, laba berasal dari penjualan dan keputusan investasi yang dilakukan perusahaan. Tingkat profitabilitas diproksikan melalui $R O E$ (Return on Equity). ROE dirumuskan sebagai berikut:

$$
\text { ROE }=\frac{\text { Laba Bersih Setelah Pajak }}{\text { Total Ekutitas }}
$$

ROE merupakan tingkat pengembalian atas investasi pemegang saham yang diukur dengan membandingkan laba bersih setelah pajak terhadap total ekuitas.

Keputusan Investasi

Keputusan investasi didefinisikan sebagai kombinasi antara aktiva yang dimiliki (assets in place) dan pilihan investasi di masa yang akan datang dengan net present value positif (Myers dalam Wijaya dkk, 2010). Sedangkan menurut Kallapur dan Trombley dalam Wijaya dan Wibawa: 2010, IOS tidak dapat diobservasi secara langsung (laten), sehingga dalam perhitungannya menggunakan proksi. Sedangkan menurut Brigham dan Houston dalam Wijaya dan Wibawa (2010) proksi IOS yang digunakan dalam penelitian ini adalah Price Earning Ratio (PER). PER menunjukan perbandingan antara harga saham (closing price) dengan laba per lembar saham (Earning Per Share).

$$
\mathrm{PER}=\frac{\text { Harga Saham }}{\text { EPS }}
$$


Keputusan Pendanaan

Keputusan pendanaan didefinisikan sebagai keputusan yang menyangkut komposisi pendanaan yang dipilih oleh perusahaan (Hasnawati, 2005). Keputusan pendanaan diproksikan melalui Debt to Equity Ratio (DER). Semakin tinggi nilai DER mengidentifikasikan semakin tinggi hutang perusahaan. Perusahaan yang memiliki hutang akan membayar bunga pinjaman yang akan mengurangi penghasilan kena pajak. Pengurangan pajak ini akan menambah laba perusahaan dimasa yang akan datang ataupun untuk membagikan dividen tersebut dilakukan oleh perusahaan maka penilaian investor terhadap perusahaan akan meningkat ditujukan dengan naiknya harga saham yang merupakan indikator nilai perusahaan (Beirlian, 2012). DER dapat dirumuskan sebagai berikut:

$$
\text { DER }=\frac{\text { Total Hutang }}{\text { Total Ekuitas }}
$$

DER menunjukkan perbandingan antara pembiayaan dan pendanaan melalui hutang dengan pendanaan melalui ekuitas (Brigham dan Houston dalam Wijaya dkk, 2010).

Kebijakan Dividen

Kebijakan deviden dalam penelitian ini didefinisikan sebagai laba yang dibagikan perusahaan kepada pemegang saham atas saham yang dimilikinya. Menurut (Sumantoro dalam Wibowo, 2008) kebijakan dividen yaitu keputusan yang diambil perusahaan apakah laba yang diperoleh akan dibagikan kepada pemegang saham sebagai dividen atau akan ditahan dalam bentuk laba ditahan guna pembiayaan investasi di masa yang akan datang. Kebijakan dividen diproksikan melalui Dividend Payout Ratio (DPR). Niali DPR yang tinggi pasti akan berimbas pada pembagian laba yang besar oleh perusahaan kepada pemegang saham. DPR dapat dirumuskan sebagai berikut:

$$
\mathrm{DPR}=\frac{\text { Divien per Lembar Saham }}{\text { Laba per Lembar Saham }}
$$

DPR menunjukkan perbandingan antara deviden per lembar saham dengan laba per lembar saham.

\section{Analisis Data}

\section{Uji Asumsi Klasik}

Normalitas

Uji normalitas ini bertujuan untuk menguji apakah dalam model regresi, variabel bebas dan variabel terikat keduanya memiliki distribusi normal atau tidak (Ghozali, 2005). Model regresi yang baik adalah memiliki data berdistribusi normal. Untuk mendeteksi normalitas melalui program Eviews dengan menggunakan uji Jarque Berra (JB), diman jika prob. J-B $>\alpha(5 \%)$, maka data berdistribusi normal. Sebaliknya, jika prob. J.B $<\alpha(5 \%)$, maka data berdistribusi tidak normal.

\section{Autokorelasi}

Pemeriksaaan terhadap dugaan adanya autokorelasi dapat menggunakan Uji DurbinWatson (Ismanto dan Desta, 2010). Uji D-W merupakan salah satu uji yang banyak dipakai untuk mengetahui ada tidaknya autokorelasi. Pengambilan keputusan dapat dilakukan dengan membandingkan nilai uji D-W (d) dengan nilai tabel D-W (dL dan dU). Nilai d akan berada dikisaran 0 sampai dengan 4 dengan ketentuan sebagai berikut:

$$
\begin{array}{ll}
4-\mathrm{dL}<\mathrm{d}<4 & =\text { Mempunyai autokorelasi negative } \\
4-\mathrm{dU}<\mathrm{d}<4-\mathrm{dL} & =\text { Tidak ada kesimpulan } \\
\mathrm{dU}<\mathrm{d}<4-\mathrm{dU} & =\text { Tidak mempunyai autokorelasi } \\
\mathrm{dL}<\mathrm{d}<\mathrm{dU} & =\text { Tidak ada kesimpulan } \\
0<\mathrm{d}<\mathrm{dL} & =\text { Mempunyai autokorelasi positif }
\end{array}
$$

\section{Heteroskedastisitas}

Uji heteroskedastisitas bertujuan menguji apakah dalam model regresi terjadi ketidaksamaan variance dari residual satu pengamatan ke pengamatan yang lain. Heteroskedastisitas artinya varians variabel dalam model tidak 
sama (konstan). Uji heteroskedastisitas melalui program eviews dengan pendekatan uji white dan uji breusch-pagan-godfrey (BPG), dengan pengambilan keputusan (Ismanto dan Desta, 2012) jika Prob. Chi Square (p-value) $>0,05$ $(\alpha)$ maka tidak terjadi heteroskedastisitas. Sebaliknya, apabila Prob. Chi Square (p-value) < $0,05(\alpha)$ maka terjadi heteroskedastisitas.

Multikolinearitas

Menurut Ismanto dan Desta (2012), multikolinearitas merupakan salah satu masalah dalam analisis regresi dengan OLS, yang berarti terdapat korelasi atau hubungan yang sangat tinggi diantara variabel independen. Multikolinearitas hanya terjadi pada regresi majemuk, karena melibatkan beberapa variabel independen sehingga tidak terjadi pada regresi sederhana. Cara mendeteksi adanya masalah multikolinearitas atau tidak yaitu dengan cara mengkorelasikan antar variabel independen, apabila nilai korelasi antar variabel independen menunjukkan nilai lebih dari 0,90 maka menunjukkan adanya masalah multikolinearitas.

\section{Analisis Regresi Data Panel}

Analisis regresi data panel dimaksudkan untuk menguji pengaruh dari beberapa variabel independen terhadap satu variabel dependen dalam beberapa periode. Dalam penelitian ini model regresi yang akan dikembangkan adalah sebagai berikut:

$\mathrm{PBV}=\alpha+\beta 1 \mathrm{ROE}+\beta 2 \mathrm{PER}+\beta 3 \mathrm{DER}+\beta 4 \mathrm{DPR}+e$

\section{Uji Hipotesis (Uji t)}

Uji t digunakan untuk menguji signifikansi pengaruh masing-masing variabel bebas terhadap variabel terikat (Beirlian, 2012). Dengan kriteria penerimaan yaitu jika nilai prob. $>0.05$, maka Ha ditolak dan H0 diterima. Sebaliknya, jika probabilitas $<0.05$, maka $\mathrm{Ha}$ diterima dan $\mathrm{H} 0$ ditolak.

\section{Koefisien Determinasi}

Uji determinasi menunjukkan seberapa besar variabel-variabel independen yang ada di dalam model dapat menerangkan variabel dependen. Uji determinasi yang digunakan dalam penelitian ini adalah menggunakan determinasi $\mathrm{R}^{2}$.

\section{HASIL PENELITIAN DAN PEMBAHASAN}

\section{Asumsi Klasik}

Uji Normalitas

Berdasarkan gambar 1, dapat disimpulkan bahwa residual persamaan regresi pada penelitian ini mempunyai distribusi normal. Hal ini ditunjukkan pada nilai prob. J-B sebesar 0.658223 , yang mana lebih besar dari $\alpha 5 \%$ $(0.658223>0.05)$.

\section{Gambar 1 \\ Hasil Uji Normalitas}

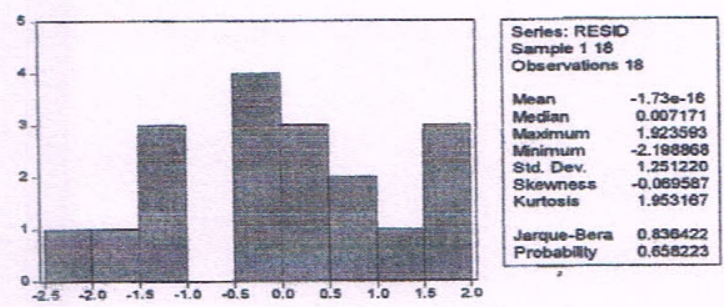

Sumber: Data diolah, 2014

Uji Autokorelasi

Dari hasil Uji D-W pada tabel 1 diperoleh nilai 1.872532. Selanjutnya untuk nilai tabel D-W, yaitu dengan $\mathrm{n}=18$ dan $\mathrm{k}=5$ diperoleh nilai $\mathrm{dL}$ $=0.522 \mathrm{dan} \mathrm{dU}=1.803$. Dengan demikian dapat disimpulkan bahwa tidak terjadi autokorelasi, dibuktikan dengan nilai $1.803<1.872532<$ 2.197.

\section{Tabel 1}

\begin{tabular}{|c|} 
Uji Durbin-Watson \\
\hline Durbin-Watson \\
\hline 1.872532 \\
\hline Sumber: Data diolah, 2014
\end{tabular}

Uji heteroskedastisitas

Dari hasil pemeriksaan terhadap gejala heteroskedastisitas dengan uji White 
dan uji Breusch-Pagan-Godfrey (BPG) pada tabel 2, keduanya menunjukkan nilai Prob. Chi Square lebih besar daripada $\alpha 5 \%(0.05)$, sehingga dapat disimpulkan bahwa tidak terjadi heteroskedastisitas.

Tabel 2

Hasil Uji Heteroskedastisitas

\begin{tabular}{|l|c|}
\hline & Prob. Chi-Square \\
\hline White & 0.2084 \\
\hline Breusch-Pagan-Godfrey & 0.0586 \\
\hline
\end{tabular}

Sumber: Data diolah, 2014

Uji Multikolinearitas

Tabel 3

Correlation

\begin{tabular}{|l|c|c|c|c|}
\hline & ROE & PER & DER & DPR \\
\hline ROE & 1.000000 & -0.732789 & -0.246207 & -0.305208 \\
\hline PER & -0.732789 & 1.000000 & 0.266838 & 0.297600 \\
\hline DER & -0.246207 & 0.266838 & 1.000000 & 0.336995 \\
\hline DPR & -0.305208 & 0.297600 & 0.336995 & 1.000000 \\
\hline
\end{tabular}

Sumber: Data diolah, 2014

Pada pengujian korelasi antarvariabel independen di atas terlihat adanya nilai korelasi yang menunjukkan kurang dari $90 \%(<0.90)$ antar variabel independen. Hal ini menunjukkan tidak adanya gejala multikolinearitas.

\section{Analisis Regresi Data Panel}

Analisis regresi dilakukan dengan menggunakan program Eviews 6, dengan hasil sebagai berikut:

Tabel 4

\section{Hasil Uji Regresi Data Panel}

\begin{tabular}{|c|c|}
\hline Variabel & Coefficient \\
\hline C & -5.109928 \\
\hline ROE? & 0.134219 \\
\hline PER? & 0.247683 \\
\hline DER? & 0.553606 \\
\hline DPR? & 0.009737 \\
\hline
\end{tabular}

Sumber: Data diolah, 2014

Dari hasil tabel uji regresi data panel diatas maka diperoleh persamaan regresi sebagai berikut:
$\mathrm{PBV}=-5.109928+0.134219 \mathrm{ROE}+0.247683$
$\mathrm{PER}+0.553606 \mathrm{DER}+0.009737 \mathrm{DPR}+e$

Uji Hipotesis

Tabel 5

Hasil Uji t

\begin{tabular}{|c|c|}
\hline Variable & Prob. \\
\hline C & 0.0000 \\
\hline ROE? & 0.0000 \\
\hline PER? & 0.0000 \\
\hline DER? & 0.2805 \\
\hline DPR? & 0.0000 \\
\hline
\end{tabular}

Sumber: Data diolah, 2014

Daritabeldiatas, variabelROEmempunyai nilai probabilitas sebesar 0.0000 . Hal tersebut menunjukkan bahwa nilai probabilitas ROE lebih kecil dari $\alpha(0.0000<0.05)$. Sehingga $H_{1}$ diterima, yaitu tingkat profitabilitas berpengaruh terhadap nilai perusahaan.

Variabel PER mempunyai nilai probabilitas sebesar 0.0000 . Hal tersebut menunjukkan bahwa nilai probabilitas lebih kecil dari $\alpha(0.0000$ $<0.05$ ). Sehingga $\mathrm{H}_{2}$ diterima, yaitu keputusan investasi berpengaruh terhadap nilai perusahaan.

Variabel DER mempunyai nilai probabilitas sebesar 0.2805 . Hal tersebut menunjukkan bahwa nilai probabilitas lebih besar dari $\alpha(0.2805$ $>0.05$ ). Sehingga $\mathrm{H}_{3}$ ditolak, yaitu keputusan pendanaan tidak berpengaruh terhadap nilai perusahaan

Variabel DPR mempunyai nilai probabilitas sebesar 0.0000 . Hal tersebut menunjukkan bahwa nilai probabilitas lebih kecil dari $\alpha(0.0000$ $<0.05$ ). Sehingga $\mathrm{H}_{4}$ diterima, yaitu kebijakan dividen berpengaruh terhadap nilai perusahaan.

\section{Koefisien Determinasi}

Dari tabel di bawah, diketahui bahwa nilai R-squared sebesar 0.994987. Hal ini menunjukkan bahwa $99,4 \%$ nilai perusahaan (PBV) dapat dijelaskan oleh variasi variabel independen yaitu tingkat profitabilitas (ROE), keputusan investasi (PER), keputusan pendanaan 
(DER), dan kebijakan dividen (DPR). Sisanya sebesar $0.6 \%(100 \%$ - 99,4\%) dijelaskan oleh variabel lain diluar penelitian.

Tabel 6

Hasil Koefisien Determinasi

\begin{tabular}{|c|}
\hline R-squared \\
\hline 0.994987 \\
\hline
\end{tabular}

Sumber: Data diolah, 2014

\section{KESIMPULAN DAN SARAN}

Berdasarkan hasil analisis, maka dapat diambil kesimpulan sebagai berikut: Variabel tingkat profitabilitas (ROE) berpengaruh signifikan terhadap nilai perusahaan (PBV), hal ini ditunjukkan dengan nilai probabilitas sebesar 0.0000 lebih kecil daripada $\alpha(0.0000<0.05)$.

Variabel keputusan investasi (PER) berpengaruh signifikan terhadap nilai perusahaan (PBV), hal ini ditunjukkan dengan nilai probabilitas sebesar 0.0000 lebih kecil daripada $\alpha(0.0000<0.05)$.

Variabel keputusan pendanaan (DER) tidak berpengaruh signifikan terhadap nilai perusahaan (PBV), hal ini ditunjukkan dengan nilai probabilitas sebesar 0.2805 lebih besar daripada $\alpha(0.2805>0.05)$.

Variabel kebijakan dividen (DPR) berpengaruh signifikan terhadap nilai perusahaan (PBV), hal ini ditunjukkan dengan nilai probabilitas sebesar 0.0000 lebih kecil daripada $\alpha(0.0000>0.05)$.

Saran untuk penelitian selanjutnya yang serupa dengan penelitian ini sebaiknya periode penelitian ataujumlah perusahaan yang digunakan ditambah, tidak hanya terbatas pada perusahaan yang tergabung dalam Jakarta Islamic Index (JII), sehingga menghasilkan informasi yang lebih mendukung lagi. Jumlah rasio keuangan yang dijadikan sebagai model ditambah dan dipilih dengan rasio yang lebih berkompeten, sehingga untuk penelitian selanjutnya diperoleh kesimpulan yang lebih efetif.
Bagi investor sebaiknya harus benarbenar teliti dalam menganalisa saham sehingga mendapatkan keuntungan atau profit yang diharapkan. Hal ini dapat dilakukan dengan menggunakan faktor-faktor yang terbukti mempengaruhi nilai perusahaan atau Price to Book Value (PBV) seperti earning per share, return on assets, net profit margin, ukuran perusahaan, dan lain sebagainya.

\section{DAFTAR PUSTAKA}

Afzal, A dan Abdul R. 2012. Pengaruh Keputusan Investasi, Keputusan Pendanaan dan Kebijakan Dividen Terhadap Nilai Perusahaan. Diponegoro Journal of Accounting. Volume 1, No. 2. Hal. 1-9.

Beirlian, G. 2012. Pengaruh Keputusan Investasi Keputusan Pendanaan dan Kebijakan Dividen Terhadap Nilai Perusahaan. Skripsi. UAD. Yogyakarta.

Efni, Y., Djumilah, H., Ubud, S., dan Mintarti, R. Keputusan Investasi, Keputusan Pendanaan dan Kebijakan Dividen: Pengaruhnya terhadap Nilai Perusahaan (Studi pada Sektor Properti dan real Estate di Bursa Efek Indonesia). Jurnal Aplikasi Manajemen. Volume. 10, No. 1, Maret 2012.

Ghozali, Imam. 2005. Aplikasi Analisis Multivariate dengan Program SPSS. Edisi 3. Semarang: Badan Penerbit Universitas Diponegoro.

Halim, A. 2005. Analisis Investasi. Edisi Kedua. Salemba Empat. Malang.

Hasnawati, S. 2005. Implikasi Keputusan Investasi, Pendanaan, dan Dividen Terhadap Nilai Perusahaan Publik di Bursa Efek Jakarta. Usahawan: No. 09/ Th XXXIX. September 2005: 33-41.

Husnan, S 2000. Manajemen Keuangan Teori dan Penerapan (Keputusan Jangka Panjang), Edisi Keempat. BPFE. Yogyakarta. 
Ismanto. D dan Desta R.K. 2012. Pentunjuk Praktikum Eviews. Fakultas Ekonomi UAD. Yogyakarta.

Prapaska, Johan R. 2012. Pengaruh Tingkat Profitabilitas, Keputusan Investasi, Keputusan Pendanaan dan Kebijakan Dividen Terhadap Nilai Perusahaan. Skripsi. Universitas Diponegoro. Semarang.

Rachmawati, L.F. 2011. Pengaruh Pengungkapan CSR, Kepemilikan Institusional, dan Ukuran Perusahaan Terhadap Nilai Perusahaan (Studi Perusahaan LQ45 yang terdaftar di BEI). Skripsi. UAD. Yogyakarta.

Sartono, R.A. 2001. Manajemen Keuangan Teori dan Aplikasi. Edisi Keempat. BPFE. Yogyakarta.

Siallagan Hamonangan dan Machfoedz Mas'ud. 2006, Mekanisme Corporate Governance, Kualitas Laba dan Nilai Perusahaan. Jurnal Akuntansi Kontemporer. Volume. 1, No. 1. Hal. 179-196.

Subekti, I., dan I. W. Kusuma. 2001. Asosiasi antara Set Kesempatan Investasi dengan Kebijakan Pendanaan dan Dividen Perusahaan, serta Implikasinya pada Perubahan Harga Saham. Jurnal Riset Akuntansi Indonesia 4 (Januari 1): 4463.

Sujoko. 1999. Analisis Kandungan Informasi Dividen dan Ketepatan Reaksi Pasar: Studi Empiris di Bursa Efek Jakarta. Thesis. Program Pascasarjana Fakultas Ekonomi Universitas Gadjah Mada.
Sugiyono. 2010. Metode Penelitian Bisnis. Cetakan ke-15. Alfabeta. Bandung.

Tandelilin, E. 2001. Analisis Investasi dan Manajemen Portofolio. Edisi Pertama. BPFE. Yogyakarta.

Wahyudi, Untung., Hartini. P. Pawestri. 2006. Implikasi Struktur Kepemilikan Terhadap Nilai Perusahaan: Dengan Keputusan Keuangan sebagai Variabel Intervening. Simposium Nasional Akuntansi 9. Padang: 1-25.

Wibowo, A.T. 2008. Pengaruh Pengumuman Dividen Terhadap Harga Saham dan Abnormal Return Saham Perusahaan Perbankan yang Terdaftar pada BEI periode 2005-2007. Skripsi. UAD. Yogyakarta.

Wijaya, L.R.P., Bandi \& Anas, W. 2010. Pengaruh Keputusan Investasi, Keputusan Pendanaan dan Kebijakan Dividen Terhadap Nilai Perusahaan. Makalah Simposium Nasional Akuntansi XIII. Hal 1-21.

Yuniasih dan Wirakusuma. 2007. Pengaruh Kinerja Keuangan Terhadap Nilai Perusahaan Dengan Pengungkapan Corporate Social Responsibility dan Good Corporate Governance Sebagai Variabel Pemoderasi. Diponegoro Journal of Accounting. Volume. 1, Nomor. 2. Hal. 1-15. 